2016

\title{
Further Surface Collecting and Shovel Testing Investigations at the Sanders Site (41LR2), Lamar County, Texas
}

Timothy K. Perttula

Heritage Research Center, Stephen F. Austin State University

Bo Nelson

Heritage Research Center, Stephen F. Austin State University

Follow this and additional works at: https://scholarworks.sfasu.edu/ita

Part of the American Material Culture Commons, Archaeological Anthropology Commons, Environmental Studies Commons, Other American Studies Commons, Other Arts and Humanities Commons, Other History of Art, Architecture, and Archaeology Commons, and the United States History Commons

Tell us how this article helped you.

This Article is brought to you for free and open access by the Center for Regional Heritage Research at SFA ScholarWorks. It has been accepted for inclusion in Index of Texas Archaeology: Open Access Gray Literature from the Lone Star State by an authorized editor of SFA ScholarWorks. For more information, please contact cdsscholarworks@sfasu.edu. 
Further Surface Collecting and Shovel Testing Investigations at the Sanders Site (41LR2), Lamar County, Texas

\section{Creative Commons License}

\section{(c) (1) \&}

This work is licensed under a Creative Commons Attribution-NonCommercial 4.0 International License 


\title{
Further Surface Collecting and Shovel Testing Investigations at the Sanders Site (41LR2), Lamar County, Texas
}

\author{
Timothy K. Perttula and Bo Nelson
}

\section{INTRODUCTION}

Archaeological investigations at the Sanders site (41LR2), an important ancestral Caddo mound center and village on the Red River in Lamar County, Texas (Figure 1), have been ongoing since 2013 (Perttula 2013; Perttula et al. 2014, 2015). The latest round of work at the Sanders site primarily concerned Dr. Chester P. Walker's conducting geophysical work there in December 2014. Bo Nelson went to the site to show Walker the areas where artifactual materials have been collected from surface clusters in earlier investigations (see Perttula et al. 2014, 2015).

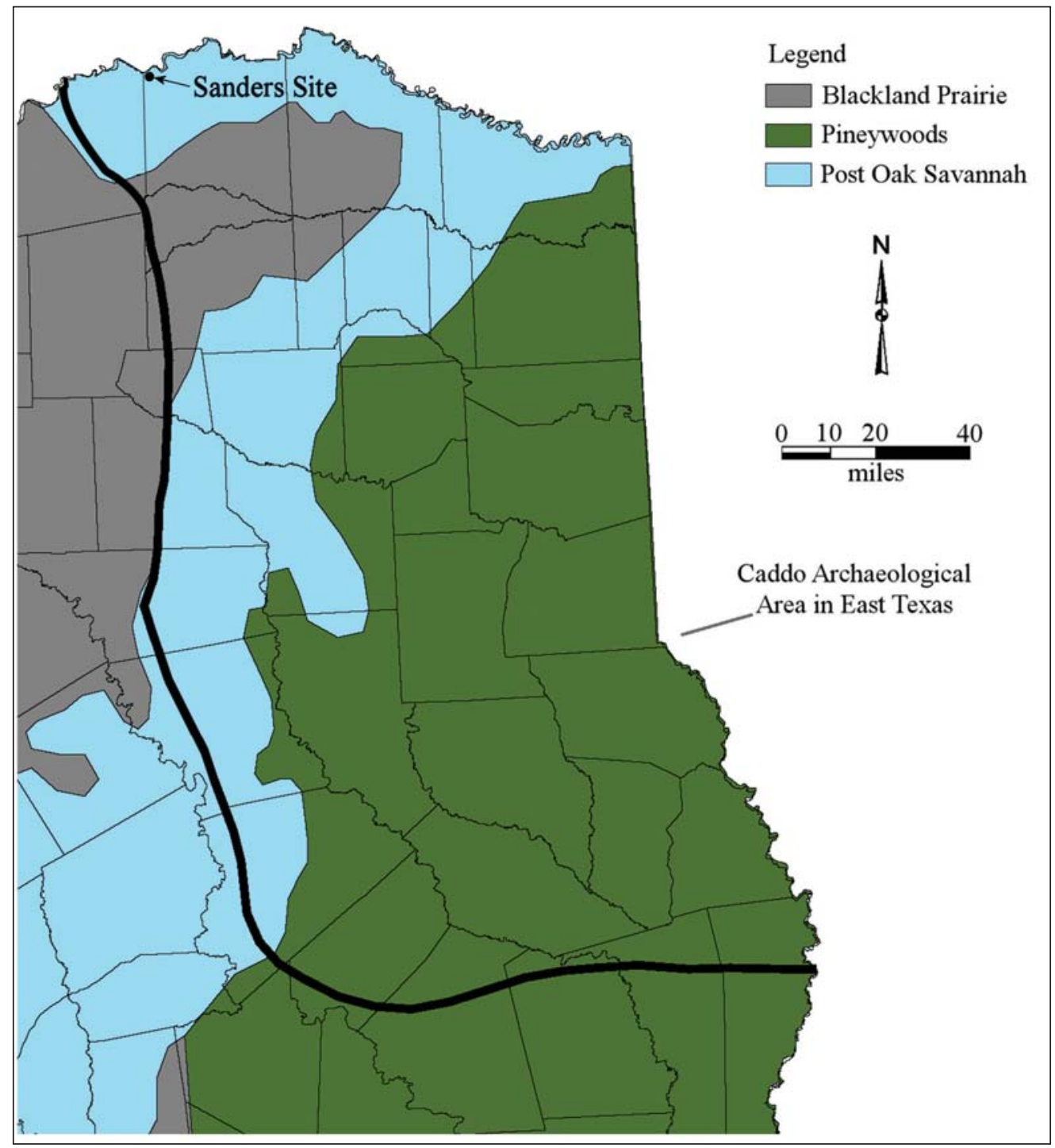

Figure 1. The location of the Sanders site in East Texas. 
The weather was cold and rainy the entire time. Dr. Walker was able to work in between rain episodes. The fields were wet and muddy. Most of the Crawford property was planted in winter wheat, except the fields just east of the mounds, that still had dried corn stalks covering the ground surface. The fields with the corn stalks had no surface visibility. The Sanders' property was recently disked, and there was about 50-60 percent surface visibility.

Mr. R. P. "Dick" Crawford, Julia Crawford's father, made several visits to the site while Nelson and Walker were there. He has a routine that involves checking for feral hogs, and seeing if there had been any damage they may have done to the fields since his last visit. During his visits, he was able to show to Nelson and Walker a small strip of property that was owned by the Crawford's that we had originally assumed to be included with the Sanders' family property. This strip of property extends up to the West mound, making the Sanders' property "L-shaped" instead of a block-shaped tract.

\section{Surface Collection Areas}

During the time that the geophysical survey work was underway by Chet Walker, Mr. Crawford visited with Joe Sanders, and according to Mr. Crawford, he had "a long heart to heart talk with Joe." Mr. Crawford secured permission for geophysical work to be conducted on the Sanders' property. In the verbal agreement, there was to be no sub-surface excavation of any type on the Sanders portion of the site.

After the agreement had been reached, and since the Sanders' property was recently disked, Nelson turned his focus to identifying areas of artifactual materials on the Sanders tract. Three new areas (Artifact Clusters 32, 33, and 34) were located with artifact concentrations, and additional artifacts were collected around the East and West mounds (Figure 2). The surface visibility was around 50 to 60 percent between organic materials recently plowed into the soil. Area 3, east of the East Mound, was not collected at that time in order to look for other areas on the Sanders' property. On both the East and West mounds, there were two areas about 2-3 $\mathrm{m}$ in diameter that contained whole and mussel shell fragments (Figure 2), and these may mark the general location of features that have been exposed in plowing.

\section{Shovel Testing Findings}

A total of 10 shovel tests were excavated at the Sanders site during December 2014 archaeological investigations. One shovel test each was excavated in Artifact Clusters 7, 11, 25, and 28 in the eastern part of the site, east of the East Mound, and six others were excavated between Artifact Cluster 9 and the West Mound at the site (see Figure 2) in an area we had learned was actually owned by the Crawford family, not the Sanders' family. The sediments in each of the shovel tests was very wet and muddy, and screening the sediments through $1 / 4$-inch mesh screens was laborious.

The shovel tests east of the East Mound are as follows:

ST 5, Artifact Cluster 11: 0-25 cm bs, dark brown silt loam; $25-53+\mathrm{cm}$ bs, reddish-brown silt loam; prehistoric artifacts were recovered from both soil zones.

ST 6, Artifact Cluster 28: 0-22 cm bs, dark brown silt loam; 22-54+ $\mathrm{cm}$ bs, reddish-brown silt loam; prehistoric artifacts recovered only in the upper soil zone.

ST 7, Artifact Cluster 25: 0-52+ cm bs, reddish-brown silt loam; prehistoric artifacts recovered only in the upper part of this soil zone.

ST 8, Artifact Cluster 7: 0-13 cm bs, dark brown silt loam; $13-48+\mathrm{cm}$ bs, reddish-brown silt loam; prehistoric artifacts recovered only in the lower soil zone. 


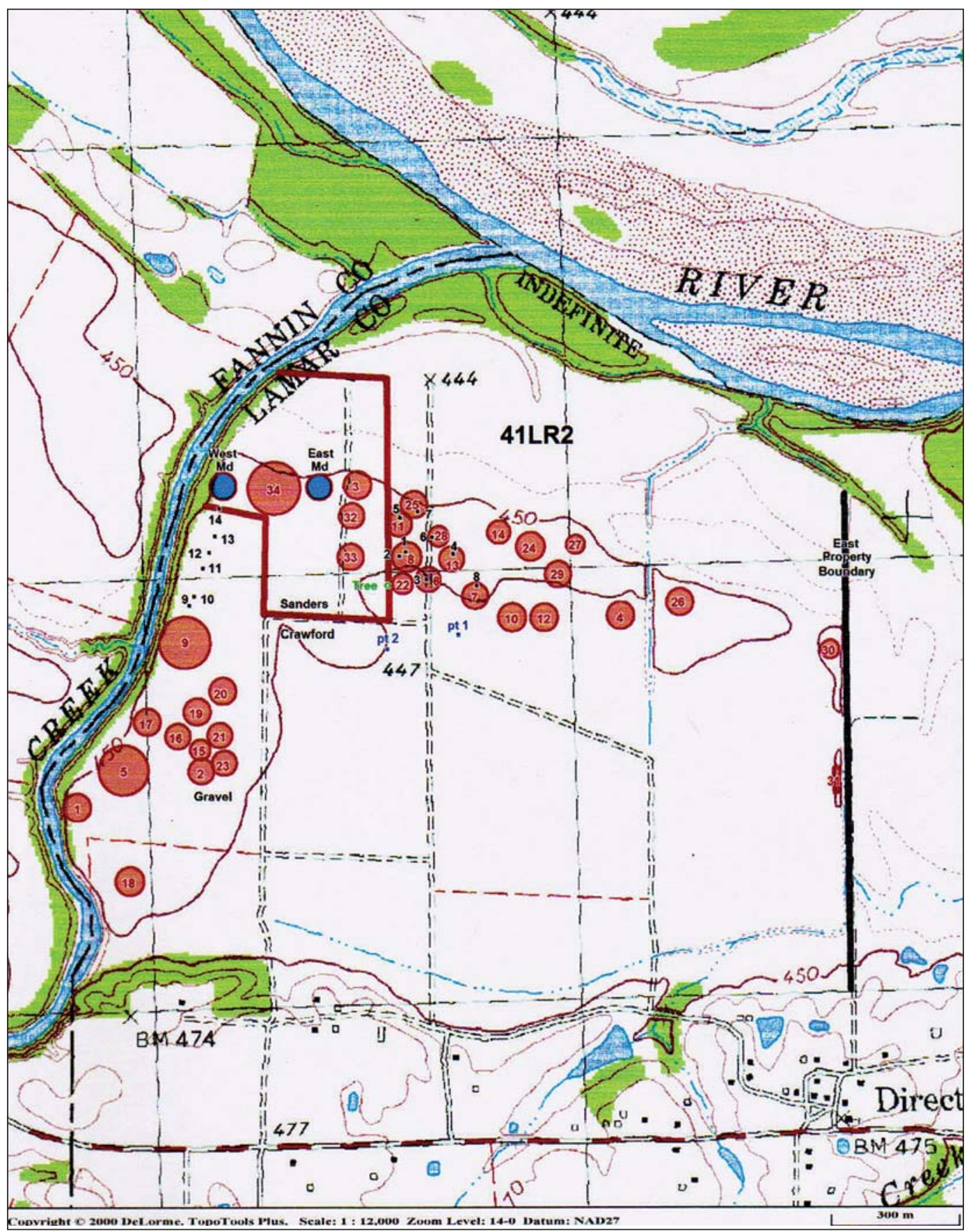

Figure 2. Surface Artifact Clusters 1-34, East, and West Mounds, and the location of ST 1-14 at the Sanders site (41LR2).

The western series of six shovel tests at the site are as follows:

ST 9: 0-34 cm bs, reddish-brown silt loam; $34-37+\mathrm{cm}$ bs, dark reddish-brown clayey loam; prehistoric artifacts recovered in the silt loam zone.

ST 10: 0-45 cm bs, reddish-brown silt loam; $45-48+\mathrm{cm}$ bs, dark reddish-brown clayey loam; prehistoric artifacts recovered in the upper silt loam zone. 
ST 11: 0-42 cm bs, reddish-brown silt loam; $42-45+\mathrm{cm}$ bs, dark reddish-brown clayey loam; prehistoric artifacts recovered in the upper silt loam zone.

ST 12: 0-41 cm bs, reddish-brown silt loam; 41-44+ cm bs, dark reddish-brown clayey loam; prehistoric artifacts recovered in the upper silt loam zone.

ST 13: 0-34 cm bs, dark reddish-brown silt loam; 34-37+ cm bs, dark reddish-brown clayey loam; prehistoric artifacts recovered in the upper silt loam zone.

ST 14: 0-34 cm bs, dark reddish-brown silt loam; 34-53+ cm bs, reddish-brown silt loam; prehistoric artifacts recovered from both silt loam zones.

\section{Artifact Analyses}

Ancestral Caddo artifacts are abundant in the intra-site areas at the Sanders site investigated in December 2014, and ceramic vessel sherds are by far the most common artifact class. Area 32 southeast of the East Mound (see Figure 2) also has a number of $20^{\text {th }}$ century artifacts, suggesting it was the location of a farmstead, perhaps a tenant farm on the Sanders property.

\section{Shovel Tests}

All 10 of the excavated shovel tests contain archaeological deposits and associated artifacts in silt loam deposits no more than ca. $40 \mathrm{~cm}$ in thickness (Table 1). The recovered artifacts include grog-, bone-, and shell-tempered plain and decorated ceramic vessel sherds, flake tools, lithic debris, and animal bone in two of the shovel tests. The shovel tests contain between 1-10 artifacts, with a mean density of 3.3 artifacts per shovel test or ca. 26.4 artifacts per $\mathrm{m}^{2}$. The highest densities are in ST 5 in Artifact Cluster 11 well southeast of the East Mound and in ST 14 not far south of the West Mound (see Figure 2).

Table 1. Artifacts recovered in the December 2014 shovel tests at the Sanders site (41LR2).

\begin{tabular}{lllllll}
\hline ST No. & $\begin{array}{l}\text { Plain } \\
\text { Sherd }\end{array}$ & $\begin{array}{l}\text { Decorated } \\
\text { Sherd }\end{array}$ & Tool & Lithic Debris & Animal Bone & N \\
\hline 5 & 3 & - & - & 2 & 1 & 6 \\
6 & - & - & - & 1 & - & 1 \\
7 & 1 & - & - & - & - & 1 \\
8 & 2 & - & 1 & - & - & 3 \\
9 & - & 1 & 1 & 1 & - & 3 \\
10 & 1 & - & - & 1 & - & 2 \\
11 & 1 & 1 & - & 1 & - & 3 \\
12 & - & - & - & 3 & - & 1 \\
13 & 1 & - & - & - & - & 10 \\
14 & 4 & 1 & - & 1 & 5 & 33 \\
\hline Totals & 13 & 3 & 2 & 10 & 5 & \\
\hline
\end{tabular}

The plain body or base sherds are from grog- $(n=9)$, bone $-(n=2)$, and shell $-(n=2)$ tempered vessels. The shell-tempered sherds are in ST 7 (Artifact Cluster 25) and ST 14 near the West Mound. The three decorated sherds are from grog-tempered vessels. They include two horizontal engraved rim sherds (from Hickory Engraved vessels) in ST 9 and ST 14 and a red-slipped Sanders Plain (cf. Brown 1996) rim sherd from ST 11. 
One of the chipped stone tools is a unilateral flake tool of black chert (with cortex) from ST 8; it has a $16.9+\mathrm{mm}$ use-worn area along one flake edge. The other is a dark gray chert side scraper in ST 9. The scraper fragment has a $20.3+\mathrm{mm}$ use-worn edge.

The lithic debris includes pieces of gray chert ( $\mathrm{n}=1,0$ percent cortical), dark gray chert $(\mathrm{n}=2,0$ percent cortical), very dark gray chert ( $\mathrm{n}=2,0$ percent cortical), grayish-brown chert $(\mathrm{n}=1,100$ percent cortical), brownish-gray chert ( $\mathrm{n}=1,0$ percent cortical), black chert $(\mathrm{n}=1,100$ percent cortical), quartzite $(\mathrm{n}=1 / 0)$, and a gray chert single platform core fragment from ST 5. Ninety percent of the lithic debris is from high quality chert raw materials likely available in local Red River gravels; their ultimate source is the Ouachita Mountains of southeastern Oklahoma. Twenty percent of the lithic debris and cores have stream-rolled cortical remnants.

\section{Artifact Cluster 32}

This artifact cluster is within $50 \mathrm{~m}$ of the East Mound (see Figure 2). The 28 sherds are from grog$(n=19,68$ percent), bone- $(n=3,11$ percent), and shell-tempered $(n=6,21$ percent) sherds. Two of the grogtempered sherds are from exterior red-slipped Sanders Plain vessels, and another grog-tempered sherd is from a Monkstown Fingernail Impressed vessel (Figure 3e) (see Suhm and Jelks 1962).

Three chipped stones are in the Artifact Cluster 32 collection: two side scrapers and a unilateral flake tool. The scrapers are on a gray chert and a dark grayish-brown chert, and have scraping edges that are $16.0+$ $\mathrm{mm}$ in length. The flake tool, on a non-cortical gray novaculite flake, has one use-worn edge that is 17.9+ $\mathrm{mm}$ in length.

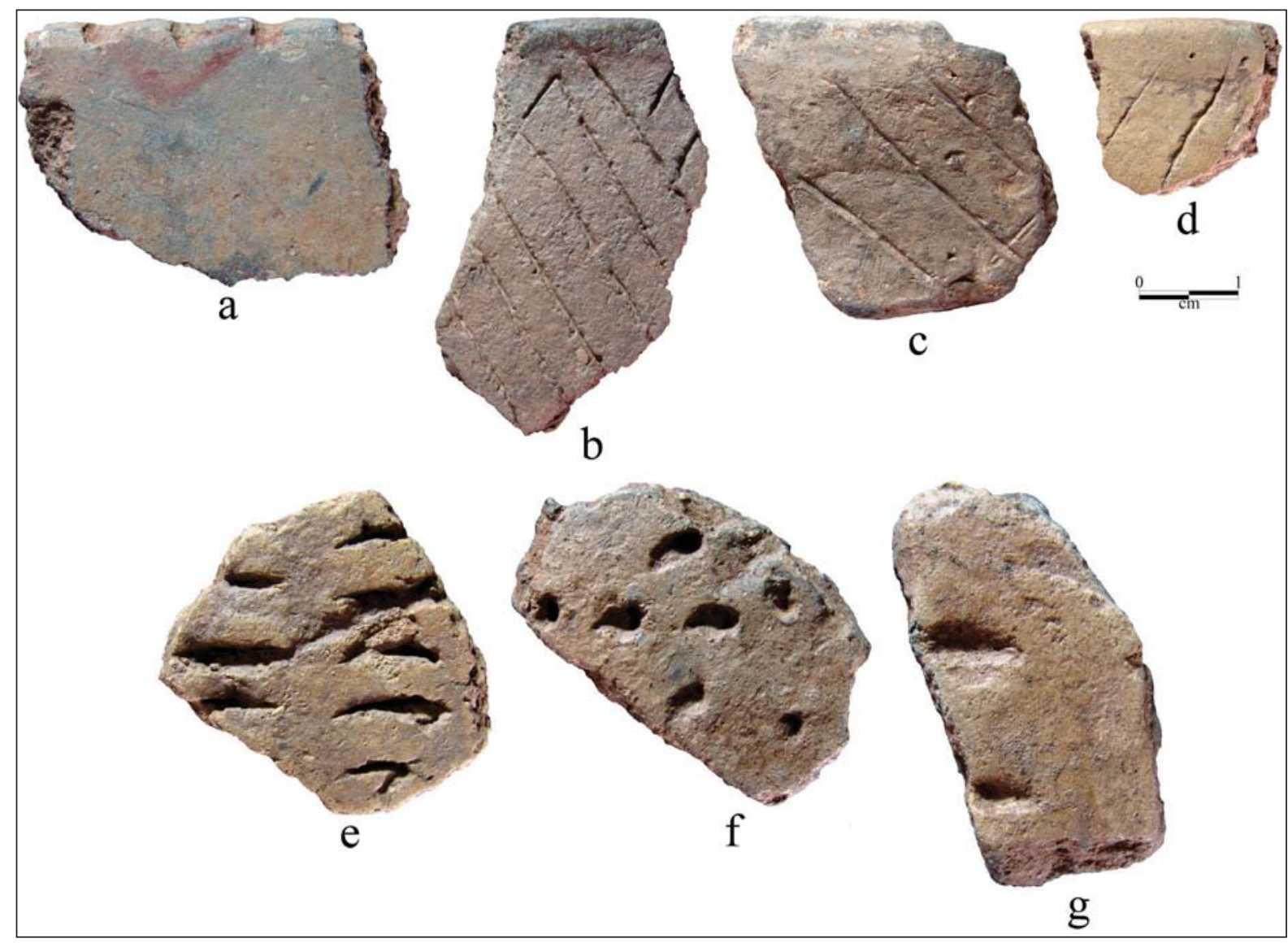

Figure 3. Selected utility ware decorated sherds in Artifact Clusters at the Sanders site: a, lip notched; b-d, Canton Incised rim sherds; e, g, Monkstown Fingernail Impressed body sherds; f, tool punctated body sherd. 
The 36 pieces of lithic debris from this cluster include a variety of cherts available in Red River gravels, and both local and Atoka Formation (grayish-green quartzite originating in southeastern Oklahoma) quartzite pieces. The most common chert colors in the Artifact Cluster 32 are dark gray chert ( 25 percent) and dark grayish-brown chert (16.7 percent). The Atoka Formation quartzite represents 16.7 percent of the lithic debris in this artifact cluster.

Numerous late $19^{\text {th }}$-early $20^{\text {th }}$ century artifacts from a farmstead are also present in Artifact Cluster 32 . These artifacts include Bristol-glazed stoneware $(n=1)$, plain whiteware body sherds $(n=13+)$, milk glass $(n=1)$, brown bottle glass $(n=11+)$, aqua green bottle glass $(n=13+)$, and clear bottle glass $(n=51+)$. Also noted in this artifact cluster was a piece of a rubber shoe sole, aluminum can fragments, and unidentifiable metal fragments.

\section{Artifact Cluster 33}

This artifact cluster is ca. $100 \mathrm{~m}$ south-southeast of the East Mound (see Figure 2). The 16 ceramic sherds collected from this cluster include plain grog- $(n=7)$, plain bone- $(n=5)$, and plain shell- $(n=2)$ tempered body and base sherds, as well as two grog-tempered engraved body sherds. One of these body sherds has parallel engraved lines, while the other is from a Womack Engraved vessel and has a curvilinear cross-hatched zone (Figure 4b).

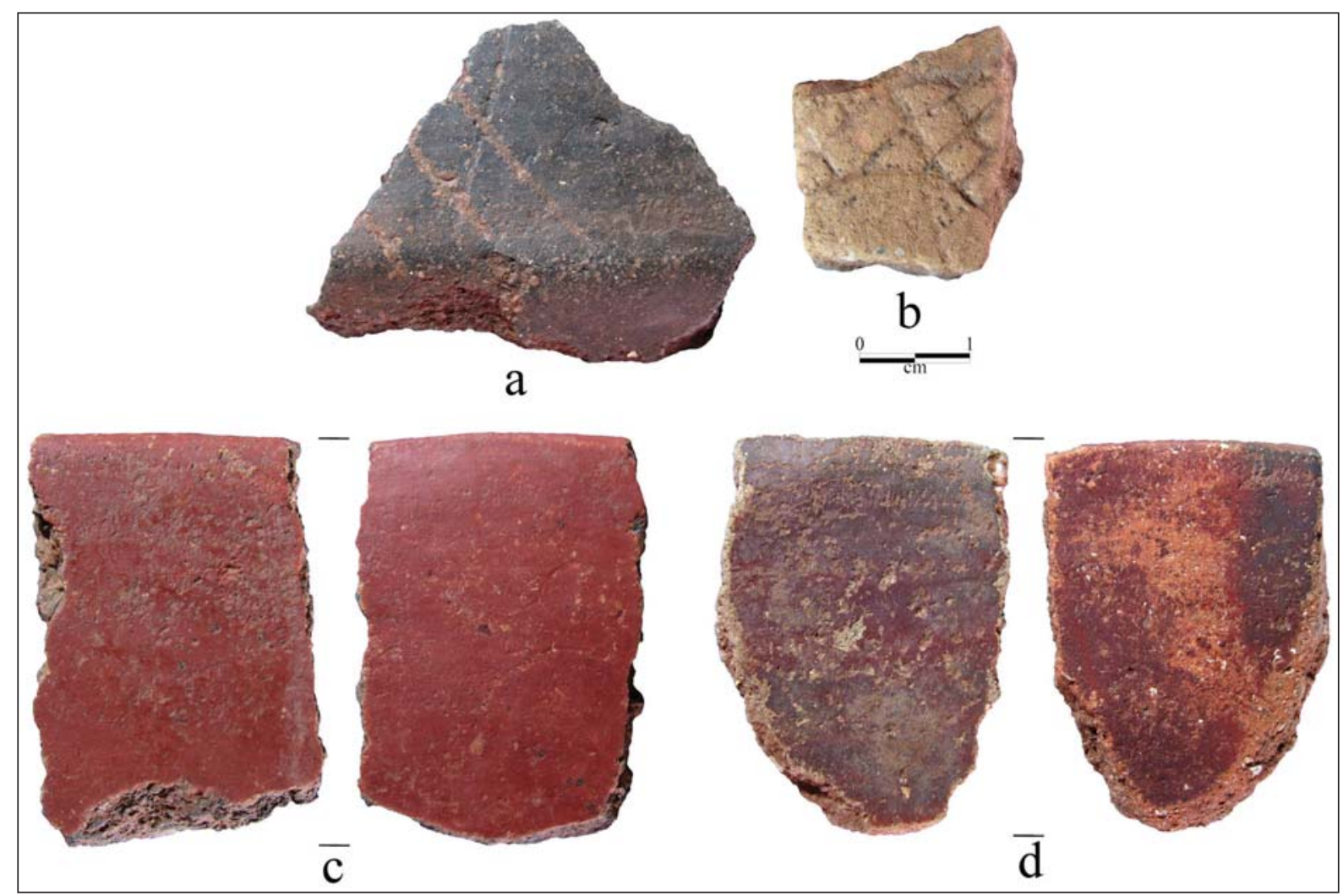

Figure 4. Selected fine ware decorated sherds in Artifact Clusters at the Sanders site: a, Sanders Engraved; b, Womack Engraved; c-d, Sanders Plain rim sherds.

There are several chipped stone tools in Artifact Cluster 33. They include a triangular arrow point (13.0 $\mathrm{mm}$ in length, $11.0 \mathrm{~mm}$ in width, and $2.3 \mathrm{~mm}$ in thickness) of light gray chert (Figure 5a), two side scraper fragments, and a expedient flake tool. One side scraper is on a non-cortical flake of dark grayish-brown chert, with a $23.0+\mathrm{mm}$ scraping edge, while the other is on a black chert, and has a $20.0+\mathrm{mm}$ scraping edge. The flake tool has a $9.3+\mathrm{mm}$ use-worn edge on a cortical flake of brown chert. 


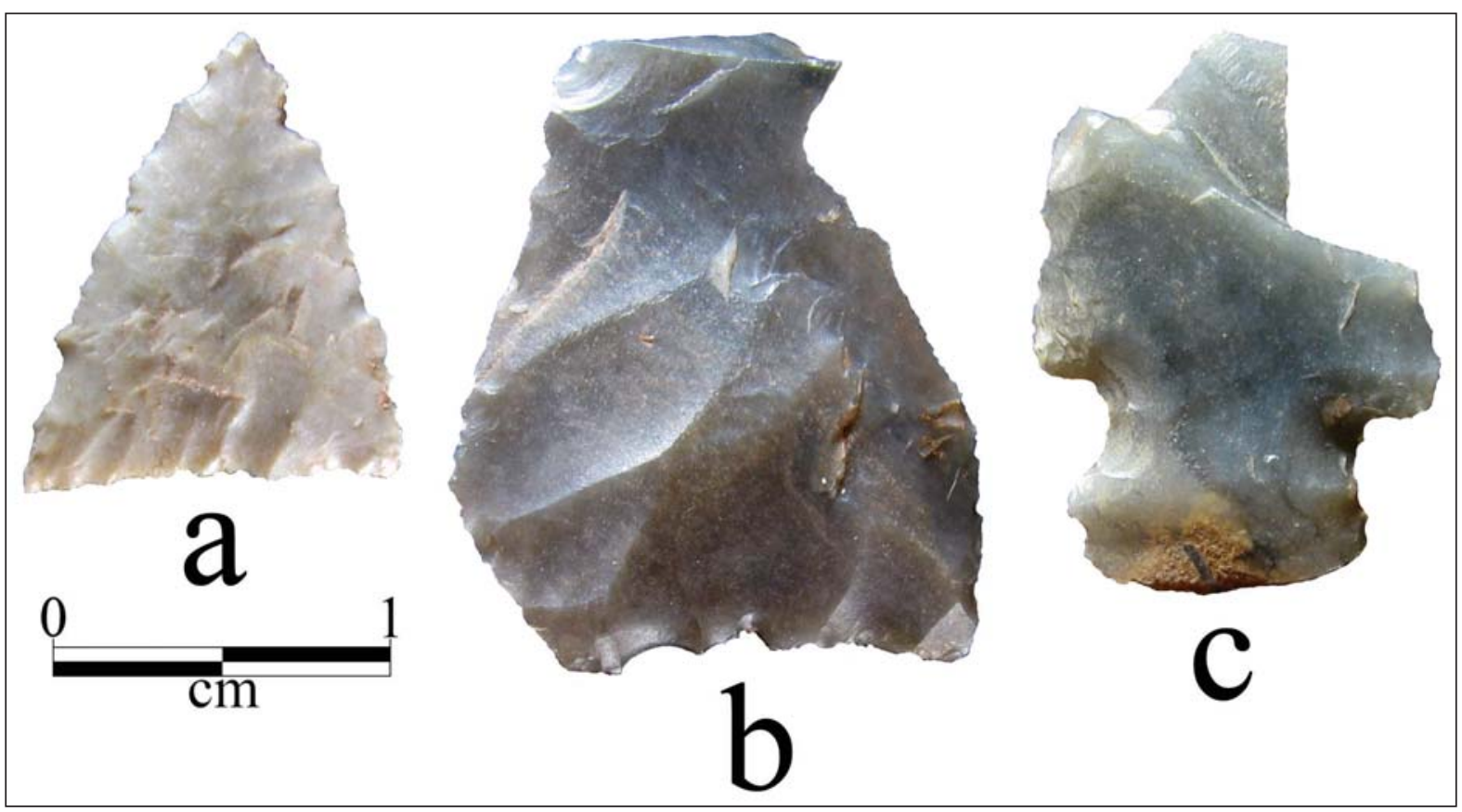

Figure 5. Arrow points from the artifact clusters at the Sanders site (41LR2): a, Artifact Cluster 33; b, Artifact Cluster 34; c, Artifact Cluster 34.

The lithic debris in this artifact cluster includes various colors of chert from Red River gravels $(\mathrm{n}=24)$ and a local quartzite $(\mathrm{n}=1)$. The most common colors of the chert are black ( 24 percent), gray (16 percent), and grayish-black ( 8 percent), very dark gray ( 8 percent), and very dark grayish-brown ( 8 percent). Twenty percent of the lithic debris have stream-rolled cortical remnants.

\section{Artifact Cluster 34}

Artifact Cluster 34 lies between the East and West Mounds at the Sanders site (see Figure 2). This is an area previously identified by Krieger (1946) as having deep midden deposits (see Perttula et al. 2015:Figure 6).

A total of 117 ceramic vessel sherds were collected from this artifact cluster, including plain and decorated grog- $(n=100,85$ percent), plain and decorated bone $-(n=13,11$ percent $)$, and plain shell-tempered $(n=4$, 3 percent) vessel sherds. The decorated grog-tempered sherds include various utility wares: parallel and diagonal opposed incised body and rim sherds $(n=2)$ from Canton Incised vessels (see Figure 3b; see also Suhm and Jelks 1962), a lip notched rim sherd (see Figure 3a), one tool punctated body (see Figure 3f), and a Monkstown Fingernail Impressed body sherd (see Figure 3g). The grog-tempered fine ware sherds have straight engraved lines $(n=3)$, and a rim with a vertical engraved line, probably from a Sanders Engraved bowl or carinated bowl. The bone-tempered decorated sherds include a Sanders Plain red-slipped rim (see Figure 4d) and a Sanders Engraved carinated bowl rim sherd with diagonal engraved lines (see Figure 4a).

Chipped stone tools are abundant in Artifact Cluster 34. Among them are a triangular arrow point fragment $(19.0+\mathrm{mm}$ in length, $15.2+\mathrm{mm}$ in width, and $3.2 \mathrm{~mm}$ in thickness) of gray chert (see Figure $5 \mathrm{~b}$ ) and a unifacially-worked Colbert arrow point $(16.4+\mathrm{mm}$ in length, $11.9 \mathrm{~mm}$ in width, and $2.3 \mathrm{~mm}$ thick) of gray chert (see Figure $5 \mathrm{c}$ ). There is also a fragment of a large gray chert biface $(36.1+\mathrm{mm}$ in length, 24.2 $\mathrm{mm}$ wide, and $6.7 \mathrm{~mm}$ thick) (Figure 6d).

The four scrapers from Artifact Cluster 34 are side scrapers ( $\mathrm{n}=2$ ) (see Figure 6c) of black and very dark gray chert, an end scraper of dark brownish-gray chert (see Figure 6b), and an end-side scraper of very dark gray chert (see Figure 6a). These scrapers range from 22.0-30.0+ mm in length, 15.9-24.9 mm in width, 


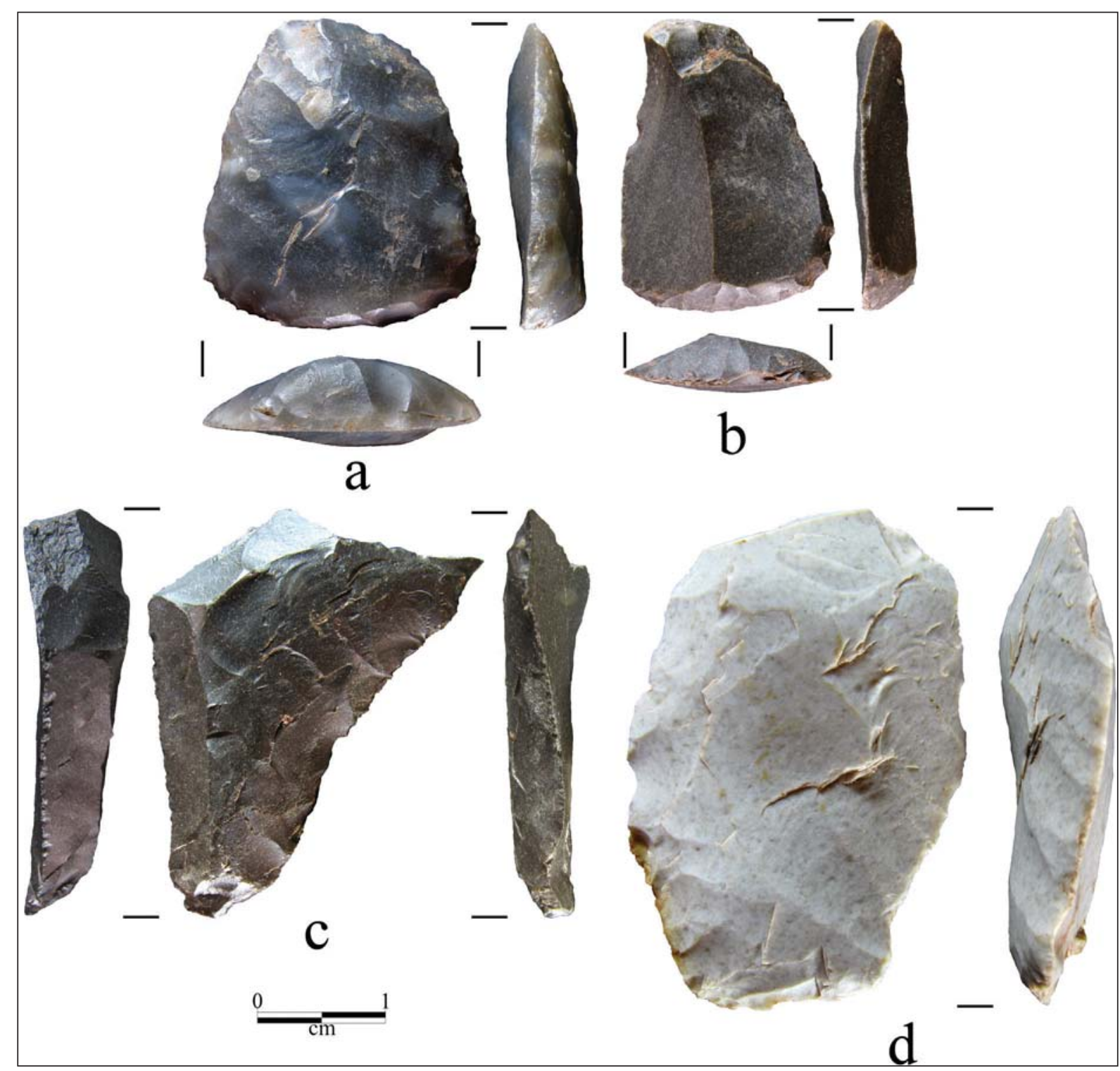

Figure 6. Chipped stone scrapers and biface from Area 34 at the Sanders site.

and are between 4.2-6.4 mm in thickness. The flake tools $(\mathrm{n}=5)$ have unilateral ( 80 percent) and bilateral (20 percent) retouched/use-worn areas. They are on quartzite $(n=1)$, brown chert $(n=1)$, dark gray chert $(n=1)$, dark grayish-brown chert $(\mathrm{n}=1)$, and very dark grayish-brown chert. Retouched/use-worn lengths range from 7.5-14.2+ mm.

The lithic debris in Artifact Cluster 34 is diverse in represented raw materials: chert ( $\mathrm{n}=28,18$ percent cortical), quartzite ( $\mathrm{n}=10,20$ percent cortical), ferruginous sandstone $(\mathrm{n}=1,100$ percent cortical), and novaculite ( $\mathrm{n}=5,0$ percent cortical). The most common raw materials in the lithic debris are very dark gray chert $(n=9,20.5$ percent), quartzite $(n=6,13.6$ percent), gray novaculite $(n=5,11.4$ percent), gray chert $(n=5$, 11.4 percent), and Atoka Formation quartzite ( $\mathrm{n}=4,9.1$ percent).

\section{East Mound}

A total of 60 sherds from grog- $(n=42,70$ percent $)$, bone- $(n=11,18$ percent $)$, and shell-tempered $(n=7$, 11.7 percent) plain and/or decorated ceramic vessels are in the surface collections from the East Mound. The 
decorated grog-tempered utility ware sherds include a Canton Incised rim (see Figure 3c), a Monkstown Fingernail Impressed rim, and two tool punctated body sherds. The grog-tempered fine ware sherds include a body sherd with parallel engraved lines and a probable grog-tempered Womack Engraved carinated bowl sherd with a diagonal-horizontal scroll line. Three bone-tempered body sherds are from Sanders Plain bottles with an exterior red-slip.

There are seven chipped stone tools from the East Mound. One is a dart point fragment of grayishbrown chert (5.6 $\mathrm{mm}$ thick). There is also an arrow point tip and blade $(2.6 \mathrm{~mm}$ thick) of a brown chert - this may be from a triangular arrow point. The other arrow point is a blade fragment ( $4.2 \mathrm{~mm}$ thick) made from a brecciated gray chert. The flake tools include two side scraper fragments and two expedient flake tools. The side scrapers are made from a brownish-gray chert and a grayish-brown chert; this scraper has a 22.0 mm working edge.

The 32 pieces of lithic debris from the East Mound surface collection include a variety of cherts of different colors $(n=24,33$ percent cortical; 75 percent), quartzite $(n=3,67$ percent cortical; 9.4 percent), Atoka Formation quartzite ( $\mathrm{n}=2,6.3$ percent), and gray novaculite ( $\mathrm{n}=3,33$ percent cortical; 9.4 percent). The most common chert colors in the lithic debris and one core fragment from this area of the site are dark gray $(n=6)$, white chert $(n=3)$, black chert $(n=3)$, and very dark grayish-brown chert $(n=3)$.

Also in the artifacts collected from the East Mound are eight pieces of unburned animal bone and at least seven mussel shell valves.

There is a small amount of late $19^{\text {th }}$-early $20^{\text {th }}$ century artifacts in the East Mound Artifact Cluster. This includes three plain whiteware body sherds and one plain Bristol glaze stoneware body sherd. These artifacts are probably related to similar historic remains in nearby Artifact Cluster 32.

\section{West Mound}

The preponderance of ceramic vessel sherds in the surface collections from the West Mound are grogtempered plain $(n=33)$ and decorated sherds $(n=7)$, approximately 91 percent of the sherds from this area. There are also plain bone-tempered $(n=3,6.8$ percent), and plain shell-tempered $(n=1,2.3$ percent) vessel sherds. The utility ware sherds from the West Mound include one Monkstown Fingernail Impressed body sherd and three Canton Incised rim (see Figure 3d) and body sherds with diagonal-horizontal, diagonal, and opposed incised decorative elements. The three fine ware sherds are rim (see Figure 4c) and body sherds from red-slipped Sanders Plain vessels.

There are three chipped stone tools in the West Mound collections. One is a large biface fragment of light grayish-brown chert; it is $7.9 \mathrm{~mm}$ thick. The second tool is a gray chert end scraper with a $16.9+\mathrm{mm}$ working edge, and the last is a unilateral flake tool of dark grayish-brown chert; the tool has a $17.1+\mathrm{mm}$ retouched-use-worn edge.

Only 12 pieces of lithic debris are in the West Mound artifact cluster. They include quartzite $(\mathrm{n}=5$, 60 percent cortical), dark gray chert $(n=2,50$ percent cortical), gray chert ( $n=1,0$ percent cortical), dark grayish-brown chert ( $\mathrm{n}=2,50$ percent cortical), black chert ( $\mathrm{n}=1,0$ percent cortical), and gray novaculite $(n=1,0$ percent cortical). More than 41 percent of the lithic debris in this artifact have stream-rolled cortical remnants.

Also in the collections from the West Mound are one piece of burned clay, at least four mussel shell valves, one unburned piece of animal bone, and one unburned deer tooth. 


\section{SUMMARY AND CONCLUSIONS}

Shovel tests and surface collections were completed at the Sanders site (41LR2) in December 2014 in conjunction with geophysical investigations done in the eastern part of the site. The 10 shovel tests were excavated in various artifact clusters in the eastern part of the site and in a tract between Artifact Cluster 9 and the West Mound (see Figure 1). The new artifact clusters include Artifact Clusters 32 and 33 southeast of the East Mound and Artifact Cluster 34 between the East and West mounds, as well as East Mound and West Mound artifact clusters (see Figure 1).

A wide variety of ceramic vessel sherds, chipped stone tools, and lithic debris were recovered in the December 2014 investigations. This includes more than 230 plain grog-, bone-, and shell-tempered sherds and 34 grog- and bone-tempered decorated sherds from utility ware and fine ware vessels (Table 2). All three tempered wares are present in the new artifact clusters, although grog-tempered sherds are by far the most common. Shell-tempered sherds are more abundant in Artifact Cluster 32 and the East Mound, suggesting they are part of a broad area within the site with probable late $17^{\text {th }}$-early $18^{\text {th }}$ century Womack phase shell-tempered ceramics east-southeast of the East Mound (see Perttula 2015:33 and Figure 26; Perttula et al. 2015:Figure 10). Except for one or two grog-tempered Womack Engraved sherds in Artifact Cluster 33 and the East Mound that are part of the Womack phase, the remainder of the decorated sherds are thought to be associated with the ca. A.D. 1100-1300 Sanders phase occupation at the Sanders site. These include sherds from Sanders Engraved, Sanders Plain, Canton Incised, and Monkstown Fingernail Impressed vessels.

Table 2. Comparison of Artifact Clusters 32-34 and the East and West Mounds at the Sanders site.

\begin{tabular}{|c|c|c|c|c|c|}
\hline $\begin{array}{l}\text { Artifact } \\
\text { Class }\end{array}$ & AC 32 & AC 33 & AC 34 & East Md. & West Md. \\
\hline Plain grog & 16 & 7 & 89 & 36 & 33 \\
\hline Plain bone & 3 & 5 & 11 & 8 & 3 \\
\hline Plain shell & 6 & 2 & 4 & 7 & 1 \\
\hline Engraved, grog & - & 2 & 4 & 2 & - \\
\hline Engraved, bone & - & - & 1 & - & - \\
\hline Red-slipped, grog & 2 & - & 2 & - & 3 \\
\hline Red-slipped, bone & - & - & 1 & 3 & - \\
\hline Finger Punct., grog & 1 & - & 1 & 1 & 1 \\
\hline Tool Punct., grog & - & - & 1 & 2 & - \\
\hline Incised, grog & - & - & 2 & 1 & 3 \\
\hline Lip notched, grog & - & - & 1 & - & - \\
\hline Triangular arrow point & - & 1 & 1 & - & - \\
\hline Arrow point fragments & - & - & 1 & 2 & - \\
\hline Dart point tip & - & - & - & 1 & _- \\
\hline Biface & - & - & 1 & - & $\overline{1}$ \\
\hline Scraper & 2 & 2 & 4 & 2 & 1 \\
\hline Flake tool & 1 & 1 & 5 & 2 & 1 \\
\hline Lithic Debris & 36 & 25 & 44 & 32 & 12 \\
\hline $\lg$ chert & 4 & - & 4 & 2 & - \\
\hline $\mathrm{g}$ chert & 2 & 4 & 5 & - & 1 \\
\hline $\mathrm{g}-\mathrm{bl}$ chert & 1 & 2 & - & - & - \\
\hline g-br chert & - & - & 2 & - & - \\
\hline
\end{tabular}


Table 2. Comparison of Artifact Clusters 32-34 and the East and West Mounds at the Sanders site, cont.

\begin{tabular}{llllll}
\hline Artifact & AC 32 & AC 33 & AC 34 & East Md. & West Md. \\
Class & & & & & \\
\hline dg chert & 9 & - & - & 6 & 2 \\
vdg chert & - & 2 & 9 & - & - \\
vdgb chert & - & 2 & - & 3 & - \\
dgb chert & 6 & - & - & - & 2 \\
bl chert & 2 & 6 & 2 & 3 & 1 \\
br chert & 1 & 1 & 1 & 3 & - \\
br-vdgbb chert & - & - & - & 1 & - \\
br-g chert & - & 1 & 2 & 2 & - \\
w chert & 1 & 2 & 2 & 3 & - \\
w-g chert & - & 1 & - & - & - \\
w-r chert & - & - & 1 & - & - \\
y chert & - & 1 & - & - & - \\
bluish-g chert & - & 1 & - & - & - \\
br-dg chert & - & 1 & - & 1 & - \\
green chert* & 1 & - & - & - & 5 \\
quartzite & 3 & 1 & 6 & 2 & - \\
quartzite, & 6 & - & 4 & 3 & - \\
Atoka Fm. & - & - & 1 & & 1 \\
FSS & - & - & 5 & 3 & 59 \\
novaculite & - & 45 & 173 & 99 & \\
\hline Totals & 67 & & & & \\
\hline
\end{tabular}

*Big Fork chert; lg-light gray; g=gray; g-bl=grayish-black; g-br=grayish-brown; dg=dark gray; vdg=very dark gray; $\mathrm{vdgb}=$ =very dark grayish-brown; $\mathrm{dgb}=$ dark grayish brown; bl=black; br=brown; br-g=brownish-gray; $\mathrm{w}=$ white; $\mathrm{w}-\mathrm{g}=$ =whitish-gray; $\mathrm{w}-\mathrm{r}=$ whitish-red; $\mathrm{y}$-yellow; $\mathrm{br}-\mathrm{dg}=$ =brown-dark gray; FSS=ferruginous sandstone

Fine ware sherds are common in all areas at the Sanders site (Table 3), including Artifact Clusters 32-34 and the East and West Mounds. Red-slipped Sanders Plain sherds are particularly common in the surface collection areas near and on the two mounds. Utility ware sherds at the site in general are dominated by sherds with incised, fingernail punctated, and tool punctated decorative elements from Canton Incised and Monkstown Fingernail Impressed vessels that are part of the Sanders phase occupation. 
Table 3. Decorated sherds from current and earlier (Perttula et al. 2015) archaeological investigations at the Sanders site.

\begin{tabular}{lll}
\hline Decorative method & Earlier work & Current work \\
\hline Utility Ware & $9 / 5.4 \%$ & - \\
Appliqued & $2 / 1.2 \%$ & - \\
Brushed & $25 / 15.1 \%$ & $6 / 17.6 \%$ \\
Incised & - & $1 / 0.9 \%$ \\
Lip Notched & $5 / 3.0 \%$ & - \\
Neck Banded & $1 / 0.6 \%$ & - \\
Punctated-cane & $1 / 0.6 \%$ & - \\
Punctated-circular & $7 / 4.2 \%$ & $4 / 11.8 \%$ \\
Punctated-fingernail & $4 / 2.4 \%$ & $3 / 8.8 \%$ \\
Punctated-tool & & \\
& & $9 / 26.5 \%$ \\
Fine Ware & $85 / 51.2 \%$ & - \\
Engraved & $1 / 0.6 \%$ & $11 / 32.4 \%$ \\
Engraved-Punctated & $25 / 15.1 \%$ & - \\
Red-slipped & $1 / 0.6 \%$ & 34 \\
Trailed & 166 & \\
\hline Totals & &
\end{tabular}

The 29 chipped stone tools in the latest archaeological investigations at the Sanders site are dominated by scrapers ( $\mathrm{n}=11$, side, end, and side-end forms) and expedient flake tools $(\mathrm{n}=10)$ with one or more retouched/ use-worn areas (see Table 2); these tools are made on chert raw materials obtained in the gravels of the Red River. Also in the collections were two large biface fragments, a dart point tip, and five arrow points. The arrow points include two triangular forms, likely of the Fresno or Maud type, associated with the Womack phase occupation at the site, as well as one probable Sanders phase Colbert arrow point from Artifact Cluster 34.

Lithic debris in the various artifact clusters is represented by a wide variety of chert raw materials, accounting for more than 72 percent of the collected sample, that would have been available in the Red River gravels (see Table 2), as well as lesser amounts of quartzite (14.1 percent of the sample), Atoka Formation quartzite ( 8.7 percent of the sample), and novaculite (6.0 percent of the sample). The most common chert colors in the lithic debris are dark gray (11.4 percent of the lithic debris), black (9.4 percent), gray (8.1 percent), and very dark gray (7.4 percent). Those pieces of lithic debris with cortex uniformly have streamrolled cortical remnants.

\section{ACKNOWLEDGMENTS}

We thank the Sanders family and Julia Trigg Crawford and the Crawford family for providing permission to carry out archaeological surface collections and shovel testing investigations at the Sander site in conjunction with the geophysical work at the site carried out by Dr. Chester P. Walker. Future geophysical investigations under Dr. Walker's direction are planned at the Sanders site. 


\section{REFERENCES CITED}

Brown, J. A.

1996 The Spiro Ceremonial Center. The Archaeology of Arkansas Valley Caddoan Culture in Eastern Oklahoma. 2 Vols. Memoir No. 29. Museum of Anthropology, University of Michigan, Ann Arbor.

Krieger, A. D.

1946 Culture Complexes and Chronology in Northern Texas, with Extensions of Puebloan Datings to the Mississippi Valley. Publication No. 4640. The University of Texas, Austin.

Perttula, T. K.

2013 Analysis of a Small Sample of Caddo Ceramic Sherds from the T. M. Sanders Site (41LR2), Lamar County, Texas. Journal of Northeast Texas Archaeology 39:1-5.

2015 The Womack Site (41LR1), an Ancestral Caddo Settlement on the Red River in Lamar County, Texas. Journal of Northeast Texas Archaeology 52:1-38.

Perttula, T. K., B. Nelson, and M. Walters

2014 Renewed Archaeological Investigations at the Sanders Site (41LR2), Lamar County, Texas. Journal of Northeast Texas Archaeology 47:25-30.

Perttula, T. K., B. Nelson, M. Walters, and R. Z. Selden Jr.

2015 The Sanders Site (41LR2): A Middle to Historic Caddo Settlement and Mound Center on the Red River in Lamar County, Texas. Journal of Northeast Texas Archaeology 50:1-87.

Suhm, D. A. and E. B. Jelks (editors)

1962 Handbook of Texas Archeology: Type Descriptions. Special Publication No. 1, Texas Archeological Society, and Bulletin No. 4, Texas Memorial Museum, Austin. Reprinted in 2009, Gustav's Library, Davenport, Iowa. 